\title{
BMJ Open Who is engaging with lateral flow testing for COVID-19 in the UK? The COVID-19 Rapid Survey of Adherence to Interventions and Responses (CORSAIR) study
}

\author{
Louise E Smith (D) ,1,2 Henry WW Potts (D) , ${ }^{3}$ Richard Amlôt (D) ,,4 \\ Nicola T Fear (D) , ${ }^{1,5}$ Susan Michie (1) ,, 6 James Rubin (D) ${ }^{1,2}$
}

\begin{abstract}
To cite: Smith LE, Potts HWW, Amlôt $R$, et al. Who is engaging with lateral flow testing for COVID-19 in the UK? The COVID-19 Rapid Survey of Adherence to Interventions and Responses (CORSAIR) study. BMJ Open 2022;12:e058060. doi:10.1136/ bmjopen-2021-058060

- Prepublication history for this paper is available online. To view these files, please visit the journal online (http://dx.doi. org/10.1136/bmjopen-2021058060).
\end{abstract}

Received 05 0ctober 2021 Accepted 13 January 2022

Check for updates

(C) Author(s) (or their employer(s)) 2022. Re-use permitted under CC BY. Published by BMJ.

For numbered affiliations see end of article.

Correspondence to Dr Louise E Smith; louise.e.smith@kcl.ac.uk

\section{ABSTRACT}

Objectives To investigate uptake of lateral flow testing, reporting of test results and psychological, contextual and socio-demographic factors associated with testing.

Design A series of four fortnightly online cross-sectional surveys.

Setting Data collected from 19 April 2021 to 2 June 2021. Participants People living in England and Scotland, aged 18 years or over, excluding those who reported their most recent test was a polymerase chain reaction (PCR) test ( $n=6646, n \approx 1600$ per survey).

Main outcome measures Having completed at least one lateral flow test (LFT) in the last 7 days.

Results We used binary logistic regressions to investigate factors associated with having taken at least one LFT. Increased uptake of testing was associated with being vaccinated (adjusted ORs (aORs) $=1.52-2.45,95 \% \mathrm{Cl}$ 1.25 to 3.07 , analysed separately by vaccine dose), employed ( $\mathrm{aOR}=1.94,95 \% \mathrm{Cl} 1.63$ to 2.32 ), having been out to work in the last week $(\mathrm{aOR}=2.30,95 \% \mathrm{Cl} 1.94$ to 2.73 ) and working in a sector that adopted LFT early (a0R=2.54, 95\% Cl 2.14 to 3.02) . Uptake was higher in people who reported cardinal COVID-19 symptoms in the last week ( $\mathrm{aOR}=1.89,95 \% \mathrm{Cl} 1.34$ to 2.66). People who had heard more about LFTs (aOR=2.28, 95\% Cl 2.06 to 2.51) and knew they were eligible to receive regular LFTs (aOR=2.98, 95\% Cl 2.35 to 3.78) were also more likely to have tested. Factors associated with not taking a test included agreeing that you do not need to test for COVID-19 unless you have come into contact with a case (aOR=0.51, 95\% Cl 0.47 to 0.55 ).

Conclusions Uptake of lateral flow testing is low. Encouraging testing through workplaces and places of study is likely to increase uptake, although care should be taken not to pressurise employees and students. Increasing knowledge that everyone is eligible for regular asymptomatic testing and addressing common misconceptions may drive uptake.

\section{INTRODUCTION}

As the UK moves to continuous management of COVID-19 instead of disaster prevention, a variety of strategies are being used to slow

\section{STRENGTHS AND LIMITATIONS OF THIS STUDY}

$\Rightarrow$ A series of large cross-sectional surveys investigating uptake, and factors associated with uptake, of lateral flow testing in the English and Scottish population.

$\Rightarrow$ One of few studies investigating psychological, contextual and socio-demographic factors associated with uptake of testing.

$\Rightarrow$ Data were collected in the weeks immediately after the recommendation that all UK adults should take two rapid lateral flow tests (LFTs) per week.

$\Rightarrow$ Self-reported rates of having completed an LFT in the last week were higher than estimated by official agencies.

$\Rightarrow$ The behaviour and beliefs of people who have signed up to complete internet surveys may not be representative of those of the general population.

the spread of infection. It is thought that transmission while asymptomatic accounts for $24 \%$ of COVID-19 transmission. ${ }^{1}$ There is limited evidence of the effectiveness of mass asymptomatic testing programmes at slowing the spread of COVID-19 as most programmes, both in the UK and abroad, have been used in conjunction with other behavioural restrictions, making it impossible to quantify the impact of mass testing alone. ${ }^{2} 3$ However, the effectiveness of any intervention will be limited if people do not engage with that behaviour.

Since 9 April 2021, everyone in the UK has been able to access free, regular, rapid lateral flow COVID-19 testing for use when asymptomatic. ${ }^{4}$ At the time of writing, the English and Scottish Governments are recommending twice weekly lateral flow testing for all adults. Lateral flow tests (LFTs) for asymptomatic testing can be ordered online, can be collected from NHS pharmacies and are 
supplied through schools, colleges and nurseries; some universities and other employers also offer rapid testing. ${ }^{5}$ Results of these tests should be reported through a UK Government website. ${ }^{6}$ Mass asymptomatic testing was piloted in Liverpool, England, between 6 November 2020 and 30 April 2021. Findings indicated that $57 \%$ of residents in Liverpool took at least one rapid LFT over the course of the pilot ( 6 months), but uptake was substantially lower in more deprived areas (where infection rates were higher) and among non-white minoritised ethnic groups. ${ }^{78}$ Testing in the initial months was partly driven by the intense media campaign in Liverpool, and the novelty of testing at the time. As well as asymptomatic testing being available, all those with cardinal COVID-19 symptoms (high temperature, a new, continuous cough and a loss or change to sense of smell or taste) have been eligible for a polymerase chain reaction (PCR) test since 18 May 2020. ${ }^{9}$ There is considerable confusion among the public about the use of LFTs and PCR tests when symptomatic. ${ }^{10}$ Previous research indicates that uptake of testing when symptomatic is low. ${ }^{11}$

A range of factors may affect whether people engage with lateral flow testing. These can be categorised using the Capability, Opportunity, Motivation and Behaviour (COM-B) model. ${ }^{12}$ Capability encompasses the psychological and physical capacity to engage in a behaviour. It includes, for example, knowledge as to what the appropriate behaviour is (eg, knowing that you are eligible for regular testing) and when to enact it. Opportunity relates to factors outside the person, for example, testing being required by one's employer, or belonging to a group that was eligible for asymptomatic testing prior to the nationwide rollout (eg, health and social care workers, teachers, students and people who work in transport such as hauliers $)^{13-16}$ and that, in turn, may be associated with socioeconomic status or ethnicity. Motivation describes the psychological processes that energise or inhibit a behaviour and includes perceived risk associated with a disease outbreak, which may in turn be linked to greater exposure to other people (eg, during socialising) ${ }_{1}^{17}$ believing that you have immunity against COVID-19, ${ }^{18}$ believing that you could engage in a behaviour if you wanted to (self-efficacy) and perceiving the behaviour to be effective.

The aim of this study was to investigate rates of uptake of lateral flow testing and reporting of results in England and Scotland, and the psychological, contextual and socio-demographic factors associated with testing.

\section{METHODS}

\section{Design}

From January 2020, BMG Research was conducting a series of nationally representative (UK) cross-sectional surveys (weekly or fortnightly) on behalf of the Department of Health and Social Care throughout the COVID-19 outbreak. We analysed these data as part of the COVID-19 Rapid Survey of Adherence to Interventions and Responses (CORSAIR) study. ${ }^{11}$ For this study, we used data collected between 19 April 2021 and 2 June 2021 (rounds 48-51).

\section{Participants}

Participants $(n \approx 2000$ per survey) were eligible for the study if they were aged 16 years or over and lived in the UK, and were recruited from two specialist research panel providers, Respondi $(\mathrm{n}=50$ 000) and Savanta $(\mathrm{n}=31$ $500)$. Quotas were applied based on age and gender (combined) to try to match these characteristics to those of the general UK population structure. Consent was implied by participants' completion of the survey, in line with industry standards. After completing the survey, participants were then unable to participate in the subsequent three surveys; thus, all participants included in this study were unique. Participants were reimbursed in points which could be redeemed in cash, gift vouchers or charitable donations (points for this survey had a monetary value of up to 70p).

We limited the sample to people living in England or Scotland as Wales and Northern Ireland were following a different testing schedule. We excluded those under 18 years of age as many would be eligible for asymptomatic testing under school testing regimes.

To investigate uptake of lateral flow testing, we excluded people who reported that their most recent test was a PCR test or they did not know what type their most recent test was and who reported that they had completed a PCR test or who did not know what type of test they completed after developing COVID-19 symptoms.

\section{Study materials}

\section{Lateral flow testing}

Participants were asked, 'when was the last time [they] had a test for coronavirus'. Response options ranged from 'within the last 24 hours' to 'I've never had a coronavirus test'.

People who reported having a COVID-19 test in the last week were asked a series of follow-up questions. These included: how many times they had taken a COVID-19 test in the last 7 days (responses ranged from 'once' to ' 10 times or more'); how they received their most recent COVID-19 test (response options included receiving it from a care home, one's place of work, a school, further education college or university, a hospital/clinical setting, having ordered it online, collecting a pack from a local test site or taking an assisted test at a local test site, or when travelling internationally); where they reported their test result, if at all (response options included the GOV.UK website, by phone with NHS Test and Trace, to one's employer, a school, further education college or university, and to friends and family); what the result of their most recent test was (response options included 'I tested positive', 'I tested negative', 'The test was void (inconclusive)' and 'I have not received my results yet'); and which type of test they had most recently taken (response options included 'PCR test', 'lateral flow test' or 'don't 
know/unsure'). For this question, participants were given an explanation of each test ('PCR tests are sent to a lab for processing and results are sent to you usually by text or email. This includes home test kits which you need to mail in or drop off. Rapid lateral flow tests provide results within $30 \mathrm{~min}$ of taking the test (these might also be referred to as rapid antigen tests). Both tests involve swabbing the back of your nose and throat').

All participants were asked how much they had previously heard about 'free, regular rapid testing for people even if they don't have coronavirus symptoms, which uses a technology called "lateral flow testing" on a 4-point scale from 'nothing at all' to 'a great deal'. They were also asked if 'as far as [they knew, they were] eligible to receive rapid COVID-19 tests twice a week to check for coronavirus even if [they didn't] have symptoms (also known as lateral flow testing)?'. Possible responses were 'yes', 'no' and 'don't know'.

\section{Contextual factors}

All participants were asked if they had any symptoms in the past 7 days from a list of 10 (new, continuous cough; high temperature/fever; runny nose; diarrhoea; nausea/ feeling sick; vomiting; sneezing; loss of appetite; loss of sense of smell; and loss of taste). In the final round of data collection, this question was changed to ask if participants had developed any symptoms in the past 10 days (response options remained identical).

We identified people in groups who had been eligible for asymptomatic testing before it became available to everyone (people who indicated that they worked or volunteered in health or social care, education and childcare, or transport). Participants were identified as students if they specified that their employment status was 'student/on a government training programme (Nation Traineeship/Modern Apprentice)'.

Participants were asked how many times in the last 7 days they had been out of their home to go to work and to meet up with friends or family that they did not live with (responses capped at 30 ). In the last round of data collection, this question was changed to ask how many times in the past 7 days they had 'left the house to go out to work (number of days)' and 'met up with' friends or family they did not live with (responses capped at 30 ). We recoded the number of times people had been out for work into a binary variable (been out to work in the last week vs not).

\section{Psychological factors}

Participants were asked how much, if at all, they agreed that: they were confident that LFTs were accurate; regularly testing people without symptoms was an effective way to prevent COVID-19 transmission; they did not need to take an LFT unless they had come into contact with a COVID-19 case; and people who had been vaccinated did not need to be tested for COVID-19 regularly. All questions were asked on a scale from 'strongly disagree' to 'strongly agree'.
Perceived risk of COVID-19 was measured by asking participants to what extent they thought COVID-19 posed a risk to 'you personally' and 'people in the UK' on a 5-point scale from 'no risk at all' to 'major risk'.

\section{Socio-demographic factors}

Participants were asked for their sex, age, employment status, highest educational or professional qualification, ethnicity, first language and COVID-19 vaccination status. Participants were also asked whether they had any dependent children in their household, whether they or a member of their household had a chronic illness, and whether the highest earner in their household worked in a manual occupation. We computed a quadratic term for age. Region and index of multiple deprivation were derived from participants' postcode. ${ }^{19}$

Participants were also asked if they had had, or currently had, COVID-19. We recoded responses to give a binary variable (think have had COVID-19 ('I've definitely had it, and had it confirmed by a test' and 'I think I've probably had it') vs think have not had COVID-19 ('I don't know whether I've had it or not', 'I think I've probably not had it' and 'I've definitely not had it')).

We measured financial hardship by asking participants to what extent in the past 7 days they had been struggling to make ends meet, skipping meals they would usually have and were finding their current living situation difficult (Cronbach's $\alpha=0.83$ ).

\section{Patient and public involvement}

Lay members served on the advisory group for the project that developed our prototype survey material; this included three rounds of qualitative testing. ${ }^{20}$ Due to the rapid nature of this research, the public was not involved in the further development of the materials during the COVID-19 pandemic.

\section{Power}

We used a post-hoc power calculation to calculate power achieved in logistic regression analyses. With a sample size of 6646 , we had $100 \%$ power to detect small ORs $(\mathrm{OR}=1.67)^{21}$ at $\alpha=0.003$ (probability of taking an LFT in last week=0.169).

\section{Analysis}

We report uptake of lateral flow testing, how people received their most recent test and out-of-home behaviour following a positive test result descriptively.

Contextual, psychological and socio-demographic factors were identified a priori, based on theory (COM-B model) ${ }^{12}$ We ran multivariable logistic regression analyses to investigate contextual, psychological and sociodemographic factors associated with having completed at least one COVID-19 test in the last week, controlling for survey round, region, gender, age (raw and quadratic), the presence of a dependent child in the household, having a chronic illness oneself, having a household member who has chronic illness, employment status, highest earner in the household working in a manual occupation, 
index of multiple deprivation quartile $(2019),{ }^{19}$ highest educational or professional qualification, ethnicity, first language, having had COVID-19 before, vaccination status and financial hardship. For these analyses, we excluded people who reported that they did not know when their last COVID-19 test was. As we hypothesised that peoples' beliefs about the necessity for regular asymptomatic testing of people who had been vaccinated for COVID-19 might differ based on vaccination status, we investigated associations between this belief and increased uptake of testing separately in those who reported having no, one or two doses of a COVID-19 vaccine. We also hypothesised that participants who received a positive COVID-19 test or whose test result was inconclusive may perceive the risk of COVID-19 to themselves differently to those who had received a negative test. Therefore, we also investigated associations between perceived risk to oneself and increased uptake of testing, excluding people whose most recent test result was positive or inconclusive.
Due to the large number of analyses $(n=16)$ conducted on a single outcome, we used a Bonferroni correction and only report narratively results where $p<0.003$. Tables give raw $\mathrm{p}$ values.

We conducted a sensitivity analysis, running logistic regression analyses using index of multiple deprivation as a categorical variable.

\section{RESULTS}

\section{Participant characteristics}

Of participants included in analyses, $54 \%$ were female, with participants having a mean age of 49 years (table 1 ).

\section{Uptake of lateral flow testing}

Since the introduction of guidance recommending asymptomatic testing for all adults two times per week, $16.9 \%(95 \%$ CI $16.0 \%$ to $17.8 \%, \mathrm{n}=1123 / 6646)$ of people reported that they had taken a lateral flow test for

Table 1 Participant characteristics

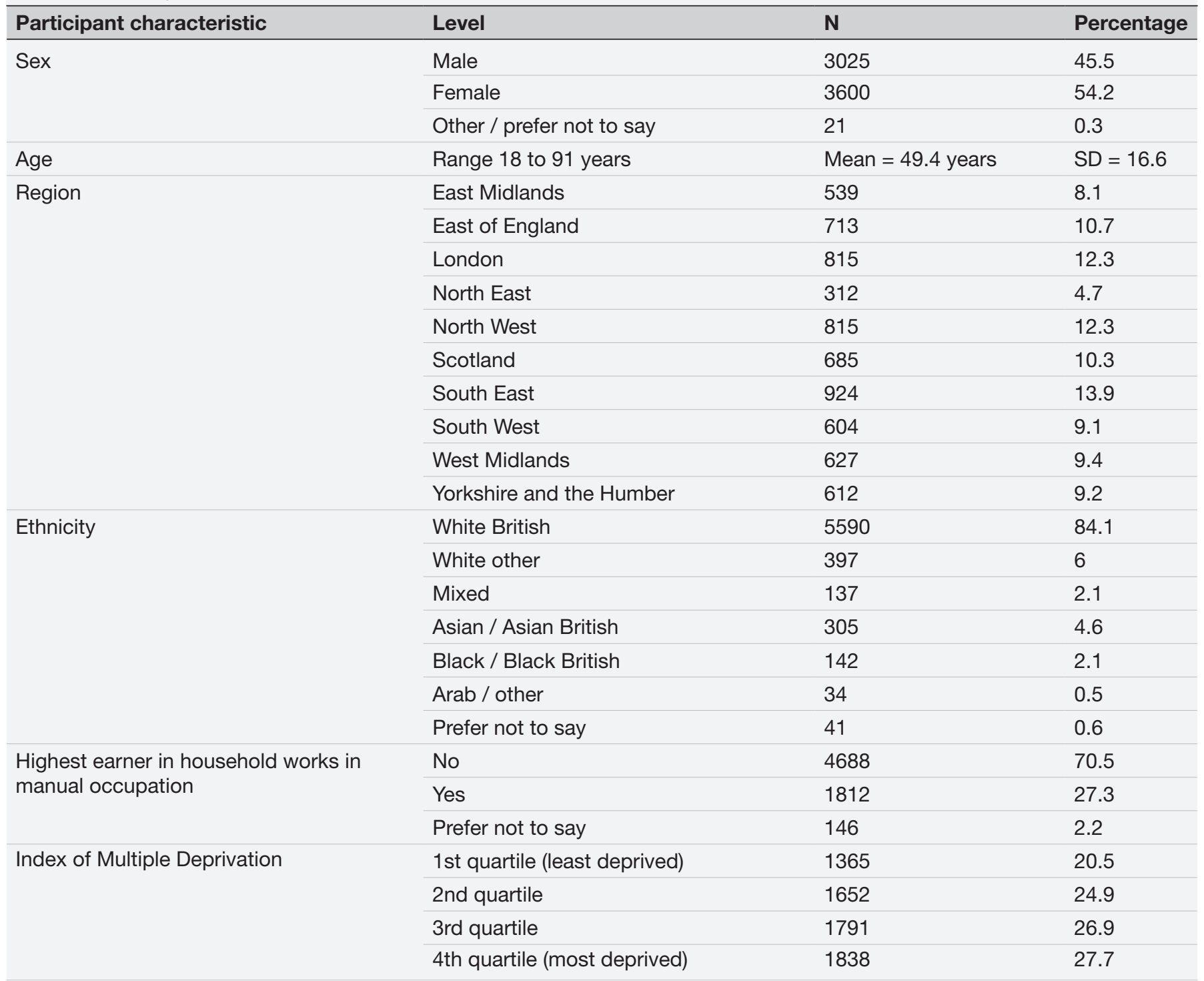


Table 2 Uptake of lateral flow testing

Asked to people who reported having a COVID-19 test in the last 7 days.

\begin{tabular}{|c|c|c|c|}
\hline $\begin{array}{l}\text { When was the last } t \\
\text { a test for coronaviru } \\
\text { interested in your } m \\
\text { even if you did not } \\
\text { (total } n=6646 \text { ) }\end{array}$ & $\begin{array}{l}\text { Ime you had } \\
\text { s? We are } \\
\text { ost recent test, } \\
\text { ave symptoms }\end{array}$ & $\begin{array}{l}\text { And how ma } \\
\text { have you tal } \\
\text { COVID-19 in } \\
\text { days? (total }\end{array}$ & $\begin{array}{l}\text { ny times } \\
\text { en a test for } \\
\text { the last } 7 \\
l=1123)\end{array}$ \\
\hline & $\%(n)$ & & $\%(n)$ \\
\hline $\begin{array}{l}\text { Within the last } 24 \\
\text { hours }\end{array}$ & $4.1(273)$ & Once & $34.3(385)$ \\
\hline 1-3 days ago & $7.4(492)$ & 2 times & $47.2(530)$ \\
\hline 4-7 days ago & $5.4(358)$ & 3 times & $9.4(106)$ \\
\hline $1-2$ weeks ago & 7.1 (469) & $4-5$ times & $3.7(42)$ \\
\hline 2-4 weeks ago & $6.9(458)$ & 6-7 times & $2.8(32)$ \\
\hline $1-3$ months ago & $10.0(666)$ & 8-9 times & $0.7(8)$ \\
\hline $3-6$ months ago & $7.8(519)$ & $\begin{array}{l}10 \text { times or } \\
\text { more }\end{array}$ & $1.2(14)$ \\
\hline $\begin{array}{l}\text { More than } 6 \text { months } \\
\text { ago }\end{array}$ & $6.3(417)$ & & \\
\hline $\begin{array}{l}\text { I have never had a } \\
\text { COVID-19 test }\end{array}$ & $43.0(2861)$ & & \\
\hline Do not know & $2.0(133)$ & Do not know & $0.5(6)$ \\
\hline
\end{tabular}

COVID-19 in the last week, excluding those whose most recent test was a PCR test (table 2). Of these, $65.2 \%$ had completed two or more tests in the last week $(11.0 \%$ total sample).

Most people reported the result of their most recent test to someone, with $64 \%$ reporting that they registered it with an official government agency (table 3 ).

\section{Associations with increased uptake of lateral flow testing}

Increased uptake of lateral flow testing was associated with: being female, younger age, having a dependent child in your household, being employed, being vaccinated, having experienced COVID-19 symptoms in the last 7-10 days, being a student, having been out to work in the last week, working in a sector that adopted lateral flow testing early (health or social care, education and childcare, and travel), having heard more about regular lateral flow testing, knowing that you are eligible for regular lateral flow testing, being confident that LFTs are accurate, agreeing that regularly testing people without symptoms is an effective way to prevent the spread of COVID-19 and perceiving a greater risk of COVID-19 to people in the UK (table 4).

Not having had a test was associated with not knowing that you were eligible for regular lateral flow testing, agreeing that you only need to take an LFT if you have come into contact with somebody who has COVID-19 and that people who have been vaccinated do not need to be tested for COVID-19 regularly (in people who reported at least one dose of the vaccine; table 4). There
Table 3 Where people register the results of their latest test

Asked to people who reported having a

COVID-19 test in the last 7 days.

\begin{tabular}{|c|c|}
\hline $\begin{array}{l}\text { How, if at all, did you report the result of your } \\
\text { test? Tick all that apply (total } n=1123 \text { ) }\end{array}$ & $\%(n)$ \\
\hline I registered my result on GOV.UK & $50.0(561)$ \\
\hline $\begin{array}{l}\text { I registered my result by phone with NHS Test } \\
\text { and Trace }\end{array}$ & $17.0(191)$ \\
\hline I informed my employer & $15.4(173)$ \\
\hline $\begin{array}{l}\text { I informed the school, nursery or further } \\
\text { education college where I or a member of my } \\
\text { family study }\end{array}$ & $6.9(77)$ \\
\hline $\begin{array}{l}\text { I informed friends/family I was planning to meet } \\
\text { after taking the test }\end{array}$ & $6.3(71)$ \\
\hline $\begin{array}{l}\text { I informed friends/family I had recently met } \\
\text { before taking the test }\end{array}$ & $5.0(56)$ \\
\hline $\begin{array}{l}\text { I informed the university where I or a member of } \\
\text { my family study }\end{array}$ & $2.5(28)$ \\
\hline Other & $2.0(23)$ \\
\hline I did not report the result to anyone & $15.8(177)$ \\
\hline $\begin{array}{l}\text { Registered test result with GOV.UK or NHS Test } \\
\text { and Trace }\end{array}$ & $64.1(720)$ \\
\hline $\begin{array}{l}\text { Registered result with anyone (GOV.UK, NHS } \\
\text { Test and Trace, one's employer or the school, } \\
\text { nursery, further education college or university } \\
\text { where the participant or a member of their family } \\
\text { study) }\end{array}$ & $77.2(867)$ \\
\hline
\end{tabular}

was significant variation by region, with Scotland showing lower uptake of lateral flow testing.

We ran a sensitivity analysis, conducting logistic regression analyses using index of multiple deprivation quartile as a categorical variable. This made minimal difference to the results.

\section{DISCUSSION}

These data suggest that uptake of lateral flow testing is low, with approximately $17 \%$ of the sample reporting having taken a test in the last week. Of the total sample, only $11 \%$ report completing at least two LFTs in the last week, in line with government recommendations. ${ }^{4}$ This is slightly lower than another survey finding that $25 \%$ of English and Scottish adults reported taking regular COVID-19 tests (defined as at least once or two times per week; data collected: 29 July 2021), although that was not in a nationally representative sample. ${ }^{22}$ These data are not directly comparable with the Liverpool pilot, which reported uptake of testing over the complete duration of the pilot (almost 6 months), rather than uptake of testing per week. ${ }^{78}$ In the first month of the pilot, $35 \%$ of people reported having taken up either an LFT or PCR test. ${ }^{23}$ Analyses of tests reported to the UK Government indicate that the number of LFTs registered had steadily declined from approximately 5.7 million LFTs (15-21 April 202124) to around 3.5 million (27 May 2021-2 June 2021). ${ }^{25}$ This 
Table 4 Factors associated with having completed at least one COVID-19 test in the last week. Bold values indicate findings significant at $p<0.003$

\begin{tabular}{|c|c|c|c|c|c|}
\hline Factor & Level & $\begin{array}{l}\text { Had not taken an LFT } \\
\text { in the last week, } n(\%) \\
\text { (total } n=5390)\end{array}$ & $\begin{array}{l}\text { Had taken at least one } \\
\text { LFT in the last week, } n \\
(\%)(\text { total } n=1123)\end{array}$ & $\begin{array}{l}\text { aOR }(95 \% \mathrm{Cl}) \text { for having } \\
\text { taken at least one LFT in } \\
\text { the last week * }\end{array}$ & $P$ value \\
\hline \multirow[t]{5}{*}{ Survey round } & 19-21 April 2021 (round 48) & $1381(84.6)$ & $252(15.4)$ & Reference & - \\
\hline & 4-5 May 2021 (round 49) & $1334(81.3)$ & $306(18.7)$ & 1.13 (0.93 to 1.38$)$ & 0.22 \\
\hline & 17-19 May 2021 (round 50) & $1326(82.6)$ & $280(17.4)$ & 1.04 (0.85 to 1.27 ) & 0.69 \\
\hline & 1-2 June 2021 (round 51) & $1349(82.6)$ & $285(17.4)$ & 0.97 (0.79 to 1.19$)$ & 0.78 \\
\hline & Overall & - & - & $\chi^{2}(3)=2.8$ & 0.42 \\
\hline \multirow[t]{11}{*}{ Region } & East Midlands & 443 (83.6) & $87(16.4)$ & Reference & - \\
\hline & East of England & $564(80.3)$ & $138(19.7)$ & 1.23 (0.90 to 1.68$)$ & 0.19 \\
\hline & London & $638(80.7)$ & $153(19.3)$ & 1.13 (0.83 to 1.55$)$ & 0.43 \\
\hline & North East & $251(81.8)$ & $56(18.2)$ & 1.22 (0.83 to 1.80$)$ & 0.31 \\
\hline & North West & $669(84.2)$ & $126(15.8)$ & 1.02 (0.75 to 1.40$)$ & 0.89 \\
\hline & Scotland & $608(90.3)$ & $65(9.7)$ & $0.53(0.37$ to 0.76$)$ & 0.001 \\
\hline & South East & $726(80.3)$ & $178(19.7)$ & 1.24 (0.92 to 1.67$)$ & 0.15 \\
\hline & South West & $504(84.3)$ & $94(15.7)$ & 1.04 (0.74 to 1.44$)$ & 0.83 \\
\hline & West Midlands & $489(79.5)$ & $126(20.5)$ & 1.35 (0.98 to 1.85$)$ & 0.07 \\
\hline & Yorkshire and the Humber & 498 (83.3) & $100(16.7)$ & 1.08 (0.78 to 1.50$)$ & 0.65 \\
\hline & Overall & - & - & $\chi^{2}(9)=35.6$ & $<0.001$ \\
\hline \multirow[t]{2}{*}{ Gender } & Male & $2508(85.0)$ & $442(15.0)$ & Reference & - \\
\hline & Female & $2868(80.9)$ & $676(19.1)$ & $1.32(1.14$ to 1.51$)$ & $<0.001$ \\
\hline Age & Raw age & $\mathrm{n}=5390, \mathrm{M}=50.6, \mathrm{SD}=16.5$ & $\begin{array}{l}n=1123, M=44.9 \\
S D=15.9\end{array}$ & $0.76(0.72$ to 0.81$)$ & $<0.001$ \\
\hline Age-quadratic (age-mean) $)^{2}$ & - & - & - & 1.0003 (1.0000 to 1.0006$)$ & 0.06 \\
\hline \multirow{2}{*}{$\begin{array}{l}\text { Dependent child in } \\
\text { household }\end{array}$} & None & $3829(85.3)$ & $660(14.7)$ & Reference & - \\
\hline & Child present & $1561(77.1)$ & $463(22.9)$ & $1.29(1.10$ to 1.51$)$ & 0.001 \\
\hline \multirow[t]{2}{*}{ Has a chronic illness (oneself) } & None & $3974(82.2)$ & $819(17.8)$ & Reference & - \\
\hline & Present & $1478(83.6)$ & $209(16.4)$ & 1.18 (1.00 to 1.39$)$ & 0.05 \\
\hline \multirow{2}{*}{$\begin{array}{l}\text { Household member has } \\
\text { chronic illness }\end{array}$} & None & $4482(82.7)$ & $936(17.3)$ & Reference & - \\
\hline & Present & $790(82.0)$ & $173(18.0)$ & 1.04 (0.86 to 1.26$)$ & 0.71 \\
\hline \multirow[t]{2}{*}{ Employment status } & Not working & $2544(88.5)$ & $330(11.5)$ & Reference & - \\
\hline & Working & $2783(78.1)$ & $781(21.9)$ & 1.94 (1.63 to 2.32$)$ & $<0.001$ \\
\hline \multirow{2}{*}{$\begin{array}{l}\text { Highest earner in household } \\
\text { works in manual occupation }\end{array}$} & No & $3844(83.6)$ & $754(16.4)$ & Reference & - \\
\hline & Yes & $1438(80.5)$ & $348(19.5)$ & $1.10(0.94$ to 1.29$)$ & 0.21 \\
\hline \multirow[t]{4}{*}{ Index of multiple deprivation $†$} & 1st quartile (least deprived) & $1125(83.7)$ & $219(16.3)$ & 0.93 (0.87 to 0.99$)$ & 0.02 \\
\hline & 2nd quartile & $1319(80.8)$ & $313(19.2)$ & & \\
\hline & 3rd quartile & $1439(82.1)$ & 314 (17.9) & & \\
\hline & 4th quartile (most deprived) & $1507(84.5)$ & 277 (15.5) & & \\
\hline \multirow[t]{2}{*}{$\begin{array}{l}\text { Highest educational or } \\
\text { professional qualification }\end{array}$} & $\begin{array}{l}\text { GCSE/vocational/A level/no formal } \\
\text { qualifications }\end{array}$ & $3625(82.9)$ & $749(17.1)$ & Reference & - \\
\hline & $\begin{array}{l}\text { Degree or higher (bachelors, masters } \\
\text { and } \mathrm{PhD} \text { ) }\end{array}$ & $1765(82.5)$ & $374(17.5)$ & 0.91 (0.78 to 1.07$)$ & 0.24 \\
\hline \multirow[t]{4}{*}{ Ethnicity } & White British & $4549(82.7)$ & 954 (17.3) & Reference & - \\
\hline & White other & 323 (83.9) & $62(16.1)$ & 0.87 (0.61 to 1.25$)$ & 0.45 \\
\hline & Black and minority ethnicity & $484(82.2)$ & $105(17.8)$ & 0.83 (0.64 to 1.08$)$ & 0.16 \\
\hline & Overall & - & - & $\chi^{2}(2)=2.1$ & 0.34 \\
\hline \multirow[t]{2}{*}{ English as a first language } & No & 415 (83.2) & $84(16.8)$ & Reference & - \\
\hline & Yes & $4975(82.7)$ & $1039(17.3)$ & 1.19 (0.86 to 1.65$)$ & 0.29 \\
\hline \multirow[t]{2}{*}{ Had COVID-19 before } & Think not & $4600(83.8)$ & $888(16.2)$ & Reference & - \\
\hline & Think yes & $790(77.1)$ & $235(22.9)$ & 1.23 (1.03 to 1.47$)$ & 0.02 \\
\hline
\end{tabular}


Table 4 Continued

\begin{tabular}{|c|c|c|c|c|c|}
\hline Factor & Level & $\begin{array}{l}\text { Had not taken an LFT } \\
\text { in the last week, } n(\%) \\
\text { (total } n=5390)\end{array}$ & $\begin{array}{l}\text { Had taken at least one } \\
\text { LFT in the last week, } n \\
(\%)(\text { total } n=1123)\end{array}$ & $\begin{array}{l}\text { aOR }(95 \% \mathrm{Cl}) \text { for having } \\
\text { taken at least one LFT in } \\
\text { the last week* }\end{array}$ & $P$ value \\
\hline \multirow[t]{4}{*}{ Vaccination status } & Not vaccinated & 1628 (82.9) & $336(17.1)$ & Reference & - \\
\hline & 1 dose & 1937 (83.2) & $392(16.8)$ & 1.52 (1.25 to 1.86$)$ & $<0.001$ \\
\hline & 2 doses & $1825(82.2)$ & $395(17.8)$ & 2.45 (1.96 to 3.07$)$ & $<0.001$ \\
\hline & Overall & - & - & $\chi^{2}(2)=61.7$ & $<0.001$ \\
\hline Financial hardship & Range: 3 (least)-15 (most) & $\mathrm{N}=5311, \mathrm{M}=7.3, \mathrm{SD}=3.0$ & $\mathrm{~N}=1107, \mathrm{M}=7.5, \mathrm{SD}=3.0$ & $0.99(0.97$ to 1.01$)$ & 0.38 \\
\hline \multirow{2}{*}{$\begin{array}{l}\text { COVID-19 symptoms in last } \\
\text { week/10 days }\end{array}$} & No & $5258(83.2)$ & $1061(16.8)$ & Reference & - \\
\hline & Yes & $132(68.0)$ & $62(32.0)$ & 1.89 (1.34 to 2.66$)$ & $<0.001$ \\
\hline \multirow[t]{2}{*}{ Being a student } & No & $5189(83.0)$ & $1061(17.0)$ & Reference & - \\
\hline & Yes & $138(73.4)$ & $50(26.6)$ & 2.65 (1.76 to 4.00$)$ & $<0.001$ \\
\hline \multirow[t]{2}{*}{ Been out to work in last week } & No & $3702(88.3)$ & $490(11.7)$ & Reference & - \\
\hline & Yes & $1688(72.7)$ & $633(27.3)$ & 2.30 (1.94 to 2.73 ) & $<0.001$ \\
\hline $\begin{array}{l}\text { Number of times been out } \\
\text { to meet people from another } \\
\text { household socially }\end{array}$ & Range: 0-30 & $\begin{array}{l}\mathrm{N}=5390, \mathrm{M}=0.9, \mathrm{SD}=1.5 \\
\text { median=0 }\end{array}$ & $\begin{array}{l}\mathrm{N}=1123, \mathrm{M}=1.2, \mathrm{SD}=1.6 \\
\text { median=1 }\end{array}$ & 1.05 (1.01 to 1.10$)$ & 0.03 \\
\hline \multirow{2}{*}{$\begin{array}{l}\text { Work in a sector that adopted } \\
\text { LFT early }\end{array}$} & No & $4700(86.3)$ & $744(13.7)$ & Reference & - \\
\hline & Yes & $690(64.5)$ & $379(35.5)$ & 2.54 (2.14 to 3.02$)$ & $<0.001$ \\
\hline $\begin{array}{l}\text { Amount heard about regular } \\
\text { LFT }\end{array}$ & $\begin{array}{l}\text { 4-point scale from 'nothing at all' to 'a } \\
\text { great deal' }\end{array}$ & $\mathrm{N}=5253, \mathrm{M}=2.8, \mathrm{SD}=0.8$ & $\mathrm{~N}=1112, \mathrm{M}=3.3, \mathrm{SD}=0.7$ & 2.28 (2.06 to 2.51$)$ & $<0.001$ \\
\hline \multirow{4}{*}{$\begin{array}{l}\text { As far as you know, are } \\
\text { you eligible to receive rapid } \\
\text { COVID-19 tests two times } \\
\text { per week to check for } \\
\text { COVID-19 even if you do not } \\
\text { have symptoms (also known } \\
\text { as lateral flow testing)? }\end{array}$} & No & $928(90.5)$ & $97(9.5)$ & Reference & - \\
\hline & Do not know & $1718(95.0)$ & $91(5.0)$ & $0.59(0.43$ to 0.80$)$ & 0.001 \\
\hline & Yes & $2744(74.6)$ & $935(25.4)$ & 2.98 (2.35 to 3.78$)$ & $<0.001$ \\
\hline & Overall & - & - & $\chi^{2}(2)=240.5$ & $<0.001$ \\
\hline $\begin{array}{l}\text { I am confident that LFTs are } \\
\text { accurate }\end{array}$ & $\begin{array}{l}\text { 5-point scale from 'strongly disagree' } \\
\text { to 'strongly agree' }\end{array}$ & $\mathrm{N}=5131, \mathrm{M}=3.3, \mathrm{SD}=1.0$ & $\mathrm{~N}=1097, \mathrm{M}=3.6, \mathrm{SD}=0.9$ & $1.40(1.29$ to 1.51$)$ & $<0.001$ \\
\hline $\begin{array}{l}\text { Regularly testing people } \\
\text { without symptoms is an } \\
\text { effective way to prevent the } \\
\text { spread of COVID-19 }\end{array}$ & $\begin{array}{l}\text { 5-point scale from 'strongly disagree' } \\
\text { to 'strongly agree' }\end{array}$ & $\mathrm{N}=5225, \mathrm{M}=3.9, \mathrm{SD}=0.9$ & $\mathrm{~N}=1115, \mathrm{M}=4.3, \mathrm{SD}=0.8$ & 1.96 (1.77 to 2.16$)$ & $<0.001$ \\
\hline $\begin{array}{l}\text { I do not need to take an } \\
\text { LFT unless I have come into } \\
\text { contact with somebody who } \\
\text { has COVID-19 }\end{array}$ & $\begin{array}{l}\text { 5-point scale from 'strongly disagree' } \\
\text { to 'strongly agree' }\end{array}$ & $\mathrm{N}=5061, \mathrm{M}=2.6, \mathrm{SD}=1.0$ & $\mathrm{~N}=1114, \mathrm{M}=2.0, \mathrm{SD}=1.1$ & 0.51 (0.47 to 0.55$)$ & $<0.001$ \\
\hline \multirow{4}{*}{$\begin{array}{l}\text { People who have been } \\
\text { vaccinated do not need to be } \\
\text { tested for COVID-19 regularly }\end{array}$} & $\begin{array}{l}\text { 5-point scale from 'strongly disagree' } \\
\text { to 'strongly agree' }\end{array}$ & & & & \\
\hline & $\begin{array}{l}\text { In people who have not been } \\
\text { vaccinated }\end{array}$ & $\mathrm{N}=1480, \mathrm{M}=2.8, \mathrm{SD}=1.1$ & $\mathrm{~N}=329, \mathrm{M}=2.7, \mathrm{SD}=1.1$ & 0.90 (0.80 to 1.01$)$ & 0.08 \\
\hline & $\begin{array}{l}\text { In people who have had one vaccine } \\
\text { dose }\end{array}$ & $\mathrm{N}=1790, \mathrm{M}=2.5, \mathrm{SD}=1.0$ & $\mathrm{~N}=385, \mathrm{M}=2.0, \mathrm{SD}=1.1$ & $0.54(0.47$ to 0.61$)$ & $<0.001$ \\
\hline & $\begin{array}{l}\text { In people who have had two vaccine } \\
\text { doses }\end{array}$ & $\mathrm{N}=1644, \mathrm{M}=2.6, \mathrm{SD}=1.0$ & $\mathrm{~N}=392, \mathrm{M}=2.0, \mathrm{SD}=1.1$ & $0.53(0.47$ to 0.60$)$ & $<0.001$ \\
\hline \multirow[t]{2}{*}{$\begin{array}{l}\text { Perceived risk of COVID-19 } \\
\text { to self }\end{array}$} & $\begin{array}{l}\text { 5-point scale from 'no risk at all' to } \\
\text { 'major risk' }\end{array}$ & $\mathrm{N}=5343, \mathrm{M}=3.0, \mathrm{SD}=1.1$ & $\mathrm{~N}=1117, \mathrm{M}=3.0, \mathrm{SD}=1.1$ & 1.04 (0.98 to 1.11$)$ & 0.23 \\
\hline & $\begin{array}{l}\text { Excluding people who tested } \\
\text { positive and whose test result was } \\
\text { inconclusive }\end{array}$ & $\mathrm{N}=5343, \mathrm{M}=3.0, \mathrm{SD}=1.1$ & $\mathrm{~N}=1058, \mathrm{M}=3.0, \mathrm{SD}=1.1$ & 1.03 (0.96 to 1.10$)$ & 0.42 \\
\hline $\begin{array}{l}\text { Perceived risk of COVID-19 } \\
\text { to people in the UK }\end{array}$ & $\begin{array}{l}\text { 5-point scale from 'no risk at all' to } \\
\text { 'major risk' }\end{array}$ & $\mathrm{N}=5326, \mathrm{M}=3.5, \mathrm{SD}=1.0$ & $\mathrm{~N}=1114, \mathrm{M}=3.6, \mathrm{SD}=0.9$ & 1.13 (1.05 to 1.22$)$ & 0.001 \\
\hline \multicolumn{6}{|c|}{$\begin{array}{l}\text { *Adjusting for survey round, region, gender, age (raw and quadratic), the presence of a dependent child in the household, having a chronic illness oneself, having a household member } \\
\text { who has chronic illness, employment status, highest earner in household works in manual occupation, index of multiple deprivation (continuous variable), highest educational or } \\
\text { professional qualification, ethnicity, first language, having had COVID-19 before, vaccination status and financial hardship. } \\
\text { Treated as a continuous variable. } \\
\text { aOR, adjusted odds ratio; LFT, lateral flow test. }\end{array}$} \\
\hline
\end{tabular}

number includes tests taken by children and does not include tests that have not been officially registered on the UK Government website. However, our data would imply around 10 million LFTs should be reported each week by people aged over 17 years in England and Scotland alone, suggesting that our survey respondents may 
be more compliant (uptake of testing and/or reporting of testing) than the general population. This is corroborated by official figures estimating that approximately $21 \%$ of LFTs are reported. ${ }^{26}$ Our data indicate that $64 \%$ of participants' most recent tests had been registered with an official government agency.

Factors related to employment or study were associated with uptake of lateral flow testing. People were more likely to report having a test in the last week if they were employed, had been out to work in the last week, and if they worked in a sector that recommended asymptomatic testing before the national guidance was implemented. Students were also more likely to report having tested in the last week. This could be because people were encouraged or compelled to take tests through their workplace, because they were more familiar with testing, or because they were more worried or perceived a greater risk of exposure to COVID-19 as they were going out to their place of work or study. ${ }^{27}$ The current findings suggest that encouraging employees to take tests could drive uptake. However, this should be approached with caution. Qualitative research suggests that barriers to implementing testing in the workplace include perceived inaccuracy of LFTs and adding to employee burden..$^{28}$ There are also ethical issues to consider in employers putting pressure on their employees, and there is a potential resulting lack of income if workers are unable to attend their place of work if they decline.$^{29}$ Mandating testing may result in negative attitudes toward testing becoming more entrenched. ${ }^{30}$ Uptake could also be increased by making testing easier, for example, at or very near to places of work or study, drop-in rather than appointment based and with explicit paid time off for testing. From 4 October 2021, people must request a 'collect code' online or by telephone in order to collect a packet of LFTs from pharmacies. ${ }^{31}$ Previously, this was not needed. How this has impacted uptake of LFTs is not yet clear, but it is likely that this change will make LFTs less accessible to some and has the potential to negatively impact uptake.

Uptake of lateral flow testing was higher in people who reported experiencing cardinal COVID-19 symptoms (high temperature, a new, continuous cough, a loss or change to sense of smell or taste) in the last week. UK Government recommendations state that people with cardinal COVID-19 symptoms should request a PCR test, rather than rely on an LFT. It is clear that this requirement is not always being followed..$^{10}$ Research suggests that people with less severe SARS-CoV-2 manifest different symptoms at the start of infection. ${ }^{32}$ Expanding the symptom set for eligibility for a PCR test is likely to increase testing burden on NHS Test and Trace. In England, all legal restrictions on social mixing were lifted on 19 July $2021 .^{33}$ Since this date, a 7 -day average of over 20000 new COVID-19 cases per day has been recorded, ${ }^{34}$ with 527077 (21 August 2021)-1 175617 (6 September
2021) pillar 2 tests being conducted per day (data checked until 24 November 2021). ${ }^{35}$ Official communications aiming to promote engagement with Government recommendations should emphasise that people with COVID-19 symptoms should request a PCR test, as should those who test positive using an LFT.

Socio-demographic factors associated with uptake of lateral flow testing included being younger and living with a dependent child. Previous research has found these factors to be consistently associated with non-adherence to behaviours that prevent the spread of COVID-19. ${ }^{11} 1836$ However, the association between increased lateral flow testing and lower age has also been found in other data, largely driven by those of working age being more likely to complete a test. ${ }^{82}$ One possible explanation may be that younger people are less likely to work from home. ${ }^{29} 37$ Therefore, these findings may be an artefact of people testing in relation to their work or study. Official figures of registered tests indicate that asymptomatic testing in school-aged children, who are 'expected to test twice weekly $^{16}$ under the supervision of their parents, is driving uptake, with numbers of tests conducted falling during the school holidays. ${ }^{25}$ Parents may be likely to test themselves for COVID-19 while supervising their child's test. Increased uptake of testing was associated with having been vaccinated. This may reflect general adherence, with those being more likely to engage in preventive behaviours also being more likely to be vaccinated (itself a preventive behaviour).

These data indicate that people were more likely to engage in lateral flow testing if they had heard more about, and knew they were eligible for, regular LFTs. This is consistent with uptake of preventive behaviours in previous pandemics. ${ }^{38}$ In line with predictions from the protection motivation theory, ${ }^{39}$ perceiving testing to be more accurate and effective was associated with increased uptake. ${ }^{40}$ Conversely, people who agreed that you only need to take a test if you have come into contact with a COVID-19 case, and that people who have been vaccinated do not need to be tested regularly, were less likely to have taken a test in the last week. The latter belief was particularly strongly associated with low uptake in those who had been vaccinated. Taken together, these results suggest that media campaigns raising awareness that all adults are eligible for the mass asymptomatic testing programme are likely to increase uptake.

Testing alone cannot prevent transmission of disease. Only when used in conjunction with other behavioural interventions (eg, staying at home and isolating) will testing prevent transmission. Due to its consistent use in combination with other interventions, it is difficult to determine the effectiveness of asymptomatic testing programmes alone. ${ }^{23}$ One study suggests that mass testing $5 \%$ of the UK population per week would lead to a $2 \%$ mean reduction in the reproductive rate of SARS-CoV-2. ${ }^{41}$ However, this was before the implementation of vaccination. Test sensitivity and specificity, and 
prevalence of infection in the population, will affect the number of cases accurately identified and missed by tests. ${ }^{42}$ Despite initial concern over the sensitivity of LFTs, especially in asymptomatic cases where people are testing themselves ${ }^{43}$ recent data suggest that LFTs have an absolute sensitivity of over $80 \%$ to detect individuals shedding SARS-CoV-2. ${ }^{44}$

We cannot be certain that the behaviour and beliefs of those that complete internet surveys are representative of those of the general population. This is reflected in the higher reporting of LFTs in our sample compared with that reported by official agencies. However, associations within the data are still likely to be informative. ${ }^{45}$ Since data reflected self-reported behaviour, reports may be biased and influenced by social desirability or poor recall. Given that we asked about behaviour in the past week, the influence of poor recall should be low. We also mitigated this by defining uptake as having completed one test in the last week, while Government guidelines suggest two COVID-19 tests per week should be completed. Although we have data on where participants received their LFTs, we did not ask why they took their most recent tests and so cannot identify whether people are engaging in routine testing, or whether testing behaviour is driven by completing a test before socialising or attending work.

When used in tandem with self-isolation, testing can prevent the spread of COVID-19 by lowering the circulation of cases within the community. In the UK, recommendations at the time of data collection stated that people with cardinal symptoms should complete a PCR test alongside a two times per week asymptomatic mass testing programme. People who tested positive using an LFT should then complete a PCR test. Mass testing programmes aim to identify cases in the population that may otherwise have been missed. However, their effectiveness is unclear. Our study suggests that uptake of lateral flow testing in the population is low. Interventions to prevent the spread of COVID-19 are unlikely to be effective if people do not engage with the behaviour. One reason for low uptake is that people do not know they are eligible for regular asymptomatic testing. Work-related and study-related factors were associated with uptake of lateral flow testing. Encouragement of employees and students, especially those attending their place of work or study, to engage in asymptomatic testing may increase uptake. However, employers and educational institutions should exercise caution so as not to place undue pressure on employees and students to test. People with symptoms were more likely to have completed a test in the past week. Consideration should be given to how best to optimise testing in the UK (PCR and LFT), taking into account the full range of symptoms displayed early in SARS-CoV-2 infection, transmission when asymptomatic, financial cost of testing and burden on the testing system. Communications aiming to promote engagement with
Government-recommended testing should highlight that people with cardinal COVID-19 symptoms should request a PCR test rather than take an LFT.

\section{Author affiliations}

${ }^{1}$ Institute of Psychiatry, Psychology and Neuroscience, King's College London, London, UK

${ }^{2}$ NIHR Health Protection Research Unit in Emergency Preparedness and Response, London, UK

${ }^{3}$ Institute of Health Informatics, University College London, London, UK

${ }^{4}$ UK Health Security Agency, Salisbury, UK

${ }^{5}$ King's Centre for Military Health Research and Academic Department of Military

Mental Health, King's College London, London, UK

${ }^{6}$ Centre for Behaviour Change, University College London, London, UK

Contributors All authors conceptualised the study and contributed to survey materials. LES completed analyses with guidance from HWWP and GJR. LES wrote the first draft of the manuscript. HWWP, RA, NTF, SM and GJR contributed to subsequent drafts of the manuscript. LES, HWWP, RA, NTF, SM and GJR approved the final manuscript. GJR is the guarantor. The corresponding author attests that all listed authors meet authorship criteria and that no others meeting the criteria have been omitted.

Funding This work was funded by the National Institute for Health Research (NIHR) Health Services and Delivery Research programme (project reference number: 11/46/21). Surveys were commissioned and funded by Department of Health and Social Care, with the authors providing advice on the question design and selection. LES, RA and GJR are supported by the NIHR Health Protection Research Unit (HPRU) in Emergency Preparedness and Response, a partnership between the UK Health Security Agency, King's College London, and the University of East Anglia. RA is also supported by the NIHR HPRU in Behavioural Science and Evaluation, a partnership between the UK Health Security Agency and the University of Bristol. HWWP has received funding from Public Health England and NHS England. NTF is partly funded by a grant from the UK Ministry of Defence. The views expressed are those of the authors and not necessarily those of the NIHR, UK Health Security Agency, the Department of Health and Social Care or the Ministry of Defence. The Department of Health and Social Care funded data collection (no grant number).

Competing interests All authors have completed the ICMJE uniform disclosure form at www.icmje.org/coi_disclosure.pdf and declare: all authors had financial support from NIHR for the submitted work; RA is an employee of the UK Health Security Agency; HWWP has received additional salary support from Public Health England and NHS England, received consultancy fees to his employer from Ipsos MORI and has a PhD student who works at and has fees paid by Astra Zeneca; no other financial relationships with any organisations that might have an interest in the submitted work in the previous 3 years; and no other relationships or activities that could appear to have influenced the submitted work. NTF is a participant of an independent group advising NHS Digital on the release of patient data. All authors are participants of the UK's Scientific Advisory Group for Emergencies or its subgroups.

Patient and public involvement Patients and/or the public were not involved in the design, or conduct, or reporting, or dissemination plans of this research.

\section{Patient consent for publication Not applicable.}

Ethics approval This study involves human participants. This work was conducted as a service evaluation of the Department of Health and Social Care's public communications campaign and, following advice from King's College London Research Ethics Subcommittee, was exempt from ethical approval. Participants were recruited from a panel of people who had signed up to take part in online surveys. Completing the survey implied consent. This is a standard practice in market research surveys.

Provenance and peer review Not commissioned; externally peer reviewed.

Data availability statement № data are available. № additional data are available from the authors.

Open access This is an open access article distributed in accordance with the Creative Commons Attribution 4.0 Unported (CC BY 4.0) license, which permits others to copy, redistribute, remix, transform and build upon this work for any purpose, provided the original work is properly cited, a link to the licence is given, and indication of whether changes were made. See: https://creativecommons.org/ licenses/by/4.0/. 


\section{ORCID iDs}

Louise E Smith http://orcid.org/0000-0002-1277-2564

Henry WW Potts http://orcid.org/0000-0002-6200-8804

Richard Amlôt http://orcid.org/0000-0003-3481-6588

Nicola T Fear http://orcid.org/0000-0002-5792-2925

Susan Michie http://orcid.org/0000-0003-0063-6378

G James Rubin http://orcid.org/0000-0002-4440-0570

\section{REFERENCES}

1 Johansson MA, Quandelacy TM, Kada S, et al. SARS-CoV-2 transmission from people without COVID-19 symptoms. JAMA Netw Open 2021;4:e2035057.

2 Wise J. Covid-19: concerns persist about purpose, ethics, and effect of rapid testing in Liverpool. BMJ 2020;371:m4690.

3 Pavelka M, Van-Zandvoort K, Abbott S, et al. The impact of population-wide rapid antigen testing on SARS-CoV-2 prevalence in Slovakia. Science 2021;372:635-41.

4 Department of Health and Social Care. New campaign urges public to get tested twice a week, 2021. Available: https://www.gov.uk/ government/news/new-campaign-urges-public-to-get-tested-twicea-week

5 NHS. Regular rapid lateral flow coronavirus (COVID-19) tests, 2021. Available: https://www.nhs.uk/conditions/coronavirus-covid-19/ testing/regular-rapid-coronavirus-tests-if-you-do-not-havesymptoms/

6 GOV.UK. Report a COVID-19 rapid lateral flow test result, 2021. Available: https://www.gov.uk/report-covid19-result

7 University of Liverpool, NHS Test and Trace, Joint Biosecurity Centre, Public Health England, Statistics OfN. Liverpool Covid-SMART community testing pilot; evaluation report, 2021. Available: https:// www.liverpool.ac.uk/media/livacuk/research/Mass,testing,evaluation. pdf

8 Green MA, García-Fiñana M, Barr B, et al. Evaluating social and spatial inequalities of large scale rapid lateral flow SARS-CoV-2 antigen testing in COVID-19 management: an observational study of Liverpool, UK (November 2020 to January 2021). Lancet Reg Health Eur 2021;6:100107.

9 Everyone in the United Kingdom with symptoms now eligible for coronavirus tests [press release], 2020. Available: https://www. gov.uk/government/news/everyone-in-the-united-kingdom-withsymptoms-now-eligible-for-coronavirus-tests

10 Smith LE, Potts HWW, Amlôt R, et al. Do members of the public think they should use lateral flow tests (LFT) or polymerase chain reaction (PCR) tests when they have COVID-19-like symptoms? the COVID-19 rapid survey of adherence to interventions and responses study. Public Health 2021;198:260-2.

11 Smith LE, Potts HWW, Amlôt R, et al. Adherence to the test trace, and isolate system in the UK: results from 37 nationally representative surveys. BMJ 2021;372:n608.

12 Michie S, van Stralen MM, West R. The behaviour change wheel: a new method for characterising and designing behaviour change interventions. Implement Sci 2011;6:42.

13 Whitty C, Powis S. Asymptomatic NHS staff testing, 2020. Available: https://cdn.ps.emap.com/wp-content/uploads/sites/3/2020/11/ProfChris-Whitty-Prof-Stephen-Powis-to-Chair-Asymptomatic-testing-ofNHS-Staff-09.11.20.pdf-FOR-WEBSITE.pdf

14 Department for Transport. Get a coronavirus (COVID-19) test if you're an HGV or van driver, 2021. Available: https://www.gov.uk/guidance/ get-a-coronavirus-covid-19-test-if-youre-an-hgv-or-van-driver\# history

15 NHS Test and Trace. COVID-19 National Testing Programme: Schools \& Colleges handbook, 2020. https://schoolsweek.co.uk/ wp-content/uploads/2020/12/Schools_Colleges_Testing-Handbook_ version-3.3-Copy.pdf

16 Department for Education. Coronavirus (COVID-19) asymptomatic testing in schools and colleges, 2021. Available: https://www.gov. uk/government/publications/coronavirus-covid-19-asymptomatictesting-in-schools-and-colleges/coronavirus-covid-19asymptomatic-testing-in-schools-and-colleges

17 Dryhurst S, Schneider CR, Kerr J. Risk perceptions of COVID-19 around the world. J Risk Res 2020;104:1-13.

18 Smith LE, Mottershaw AL, Egan M, et al. The impact of believing you have had COVID-19 on self-reported behaviour: cross-sectional survey. PLoS One 2020;15:e0240399.

19 Ministry of Housing Communities and Local Government. The English indices of deprivation 2019 (IoD2019), 2019. Available: https://assets.publishing.service.gov.uk/government/uploads/
system/uploads/attachment_data/file/835115/loD2019_Statistical_ Release.pdf

20 Rubin GJ, Bakhshi S, Amlôt R, et al. The design of a survey questionnaire to measure perceptions and behaviour during an influenza pandemic: the flu telephone survey template (FluTEST). Health Services and Delivery Research 2014;2:1-126.

21 Chen $\mathrm{H}$, Cohen $\mathrm{P}$, Chen $\mathrm{S}$. How big is a big odds ratio? interpreting the magnitudes of odds ratios in epidemiological studies. Commun Stat Simul Comput 2010;39:860-4.

22 YouGov. At the current time are you or are you not taking regular Covid-19 tests (at least once or twice a week)? 2021. Available: https://yougov.co.uk/topics/health/survey-results/daily/2021/07/29/ f6d26/2

23 Department of Health and Social Care, NHS Test and Trace, British Army, Public Health england, Liverpool City Council, University of Liverpool. Liverpool Covid-SMART (systematic meaningful asymptomatic repeated testing) pilot; addressing SARS-CoV-2 transmission and harms from Covid-19 restrictions, as one system, 2020. Available: https://assets.publishing.service.gov.uk/ government/uploads/system/uploads/attachment_data/file/950695/ s0958-liverpool-covid-smart-evaluation.pdf

24 Department of Health and Social Care. Weekly statistics for NHS test and trace (England) and coronavirus testing (UK): 15 April to 21 April 2021, 2021. Available: https://assets.publishing.service.gov.uk/ government/uploads/system/uploads/attachment_data/file/982248/ Test_and_Trace_Week47.pdf

25 Department of Health and Social Care. Weekly statistics for rapid asymptomatic testing in England: 27 may to 2 June 2021, 2021. Available: https://www.gov.uk/government/publications/weeklystatistics-for-nhs-test-and-trace-england-27-may-to-2-june-2021/ weekly-statistics-for-rapid-asymptomatic-testing-in-england-27may-to-2-june-2021\#lfd-tests-conducted-england1

26 Department of Health and Social Care. Management information on lateral flow device (LFD) test registration rates: 22 July 2021, 2021. Available: https://www.gov.uk/government/publications/ management-information-on-lfd-test-registration-rates-22-july-2021/ management-information-on-lateral-flow-device-lfd-test-registrationrates-22-july-2021\#estimated-proportion-of-lfd-tests-dispatchedwhich-have-been-registered

27 Parker K, Horowitz JM, Minkin R. How the Coronavirus Outbreak Has - and Hasn't - Changed the Way Americans Work, 2020. Available: https://www.pewresearch.org/social-trends/2020/12/09/how-thecoronavirus-outbreak-has-and-hasnt-changed-the-way-americanswork/

28 Kierkegaard P, Micocci M, McLister A, et al. Implementing lateral flow devices in long-term care facilities: experiences from the Liverpool COVID-19 community testing pilot in care homes- a qualitative study. BMC Health Serv Res 2021;21:1153.

29 Michie S, Potts HWW, West R, et al. Factors associated with nonessential workplace attendance during the COVID-19 pandemic in the UK in early 2021: evidence from cross-sectional surveys. Public Health 2021;198:106-13.

30 Smith LE, Hodson A, Rubin GJ. Parental attitudes towards mandatory vaccination; a systematic review. Vaccine 2021;39:4046-53.

31 Pharmaceutical Services Negotiating Committee. C-19 lateral flow device distribution service, 2021. Available: https://psnc.org.uk/ services-commissioning/advanced-services/c-19-lateral-flowdevice-distribution-service/

32 Sudre $\mathrm{CH}$, Lee KA, Lochlainn MN, et al. Symptom clusters in COVID-19: a potential clinical prediction tool from the COVID symptom study APP. Sci Adv 2021;7. doi:10.1126/sciadv.abd4177. [Epub ahead of print: 1903 2021].

33 Johnson B. Prime minister confirms move to step 4, 2021. Available: https://www.gov.uk/government/news/prime-minister-confirmsmove-to-step-4 [Accessed 12 Jul 2021].

34 GOV.UK. Cases in England, 2021. Available: https://coronavirus. data.gov.uk/details/cases?areaType=nation\&areaName=England [Accessed 24 Nov 2021].

35 GOV.UK. Testing in England, 2021. Available: https://coronavirus data.gov.uk/details/testing?areaType $=$ nation\&areaName=England [Accessed 24 Nov 2021]

36 Wright L, Steptoe A, Fancourt D. Patterns of compliance with COVID-19 preventive behaviours: a latent class analysis of 20000 UK adults. J Epidemiol Community Health 2021;0:1-7.

37 Office for National Statistics. Coronavirus and homeworking in the UK: April 2020, 2020. Available: https://www.ons.gov.uk/emp oymentandlabourmarket/peopleinwork/employmentandemploye etypes/bulletins/coronavirusandhomeworkingintheuk/april2020\# homeworking-by-occupation 
38 Rubin GJ, Potts HWW, Michie S. The impact of communications about swine flu (influenza A H1N1v) on public responses to the outbreak: results from 36 national telephone surveys in the UK. Health Technol Assess 2010;14:183-266.

39 Rogers RW, Prentice-Dunn S. Protection motivation theory. In: Handbook of health behavior research 1: personal and social determinants. Plenum press, 1997.

40 van Loenhout JAF, Vanderplanken K, Scheen B, et al. Determinants of adherence to COVID-19 measures among the Belgian population: an application of the protection motivation theory. Arch Public Health 2021;79:74.

41 Kucharski AJ, Klepac P, Conlan AJK, et al. Effectiveness of isolation, testing, contact tracing, and physical distancing on reducing transmission of SARS-CoV-2 in different settings: a mathematical modelling study. Lancet Infect Dis 2020;20:1151-60.

42 Mercer TR, Salit M. Testing at scale during the COVID-19 pandemic. Nat Rev Genet 2021;22:415-26.

43 Dinnes J, Deeks JJ, Berhane S, et al. Rapid, point-of-care antigen and molecular-based tests for diagnosis of SARS-CoV-2 infection. Cochrane Database Syst Rev 2021;3:CD013705.

44 Petersen I, Crozier A, Buchan I, et al. Recalibrating SARS-CoV-2 antigen rapid lateral flow test relative sensitivity from validation studies to absolute sensitivity for indicating individuals shedding transmissible virus. Clin Epidemiol 2021;13:935-40.

45 Kohler U. Possible uses of Nonprobability sampling for the social sciences. survey methods: insights from the field, 2019. Available: https://surveyinsights.org/?p=10981 
Correction: Who is engaging with lateral flow testing for

COVID-19 in The UK? The COVID-19 Rapid Survey of Adherence to Interventions and Responses (CORSAIR) study

Smith LE, Potts HW, Amlôt R, et al. Who is engaging with lateral flow testing for COVID-19 in the UK? The COVID-19 Rapid Survey of Adherence to Interventions and Responses (CORSAIR) study. BMJ Open 2022;12:e058060. doi: 10.1136/bmjopen2021-058060

This article was previously published with an error.

There is an issue with labelling for socio-economic grade. The item for this variable asks participants to state the profession of the highest earner in the household. We categorised participants into two groups: highest earner works in a manual occupation, and highest earner does not work in a manual occupation. The levels of these variables are referred to in some of our project's manuscripts as 'socio-economic grade C1DE' and 'socio-economic grade ABC1', respectively. These would be better denoted as 'highest earner in household works in a manual occupation' and 'highest earner in household does not work in a manual occupation'. This labelling error came about through multiple iterations of documents.

Open access This is an open access article distributed in accordance with the Creative Commons Attribution 4.0 Unported (CC BY 4.0) license, which permits others to copy, redistribute, remix, transform and build upon this work for any purpose, provided the original work is properly cited, a link to the licence is given, and indication of whether changes were made. See: https://creativecommons.org/licenses/by/4.0/.

(C) Author(s) (or their employer(s)) 2022. Re-use permitted under CC BY. Published by BMJ.

BMJ Open 2022;12:e058060corr1. doi:10.1136/bmjopen-2021-058060corr1

Check for updates 